\title{
INTERLEUKIN 1A GENE POLYMORPHISMS IN ROMANIAN PATIENTS WITH SERONEGATIVE SPONDYLOARTHROPATHIES
}

\author{
Laura Ioana Cherciu' ${ }^{1}$, Marius Cherciu ${ }^{1}$, Luis Ovidiu Popa ${ }^{2}$, Mihai Bojinca ${ }^{3}$, Monica Irina Dutescu ${ }^{4}$, \\ Violeta Bojinca ${ }^{5}$, Constantin Bara ${ }^{1}$, Olivia Mihaela Popa ${ }^{1}$ \\ ${ }^{\prime}$ Department of Immunology and Pathophysiology, Faculty of Medicine, \\ Carol Davila University, Bucharest, Romania \\ ${ }^{2}$ Molecular Biology Department, Grigore Antipa National Museum of Natural History, Bucharest, Romania \\ ${ }^{3}$ Department of Rheumatology, Faculty of Medicine, Carol Davila University, \\ Dr. Ion Cantacuzino Hospital, Bucharest, Romania \\ ${ }^{4}$ Prof. Dr. C.T. Nicolau National Institute of Blood Transfusion, Bucharest, Romania \\ ${ }^{5}$ Department of Rheumatology, Faculty of Medicine, Carol Davila University, \\ Sf. Maria Hospital Bucharest, Romania
}

\begin{abstract}
Objective. The aim of this study was to investigate whether two IL1A gene polymorphisms, rs17561 and rs1800587, influence disease susceptibility for seronegative spondyloarthropathies (SpA) in Romanians. Subsequently, we analysed separately ankylosing spondylitis (AS) and psoriatic arthritis (PsA) subgroups in relation with the two IL1A gene variants.

Methods. The study included $240 \mathrm{SpA}$ patients (140 AS and 100 PsA patients) and 160 healthy controls. Real-time polymerase chain reaction (RT-PCR) was used to genotype the two single nucleotide polymorphisms (SNPs). Allele, genotype and haplotype frequencies of each SNP were compared between SpA patients and controls and also between AS and PsA cohorts and controls. The PLINK 1.9 software package was used to assess the potential associations; $p$ values $\leq 0.05$ were considered significant.

Results. The minor allele T frequency for rs 17561 polymorphism was similar in general SpA cohort (31.4\%) compared with controls $(32.8 \%)$, the statistical analyses confirming the lack of association $(p=0.67)$. Almost identical results were found for rs 1800587 : minor allele T frequency was $29.1 \%$ in SpA patients and $29.7 \%$ in controls $(p=0.85)$. The same pattern persisted for the separate analysis of HLA-B27 positive SpA patients or AS and PsA cases against controls.

Conclusions. The IL1A gene polymorphisms (rs17561 and rs1800587) do not influence the disease predisposition for seronegative spondyloarthropathies in general, nor for ankylosing spondylitis and psoriatic arthritis in particular, in Romanians.
\end{abstract}

Keywords: IL1A gene, seronegative spondyloarthropathies (SpA), ankylosing spondylitis (AS), psoriatic arthritis (PsA), single nucleotide polymorphisms (SNPs)

\section{INTRODUCTION}

Ankylosing spondylitis (AS) and psoriatic arthritis (PsA) are the most prominent representatives of the seronegative spondyloarthropathies (SpA) group, which also include reactive arthritis, $\mathrm{SpA}$ related to inflammatory bowel disease (IBD-SpA), acute anterior uveitis (AAU), juvenile spondyloarthritis and undifferentiated spondyloarthritis (uSpA) (1). Axial and peripheral asymmetrical inflammatory arthritis is the clinical hallmark for these interrelated rheumatic diseases, while the intimate association with human leucocyte antigen (HLA) B27 represents the most recognisable genetic trait $(2,3)$.

The prevalence and geographical distribution of HLA-B27 (4) influence the epidemiological profile of SpA. The lowest reported prevalence of SpA and

Correspondence address:

Olivia Mihaela Popa, PhD, Department of Pathophysiology and Immunology, Faculty of Medicine, Carol Davila University of Medicine and Pharmacy, 37 Dionisie Lupu street, Bucharest, Romania

E-mail: oliviapopa@yahoo.com 
AS was in Japan (less than 0.01\%) (5), while the highest prevalence was registered in Nordic populations: $2.5 \%$ in Alaska (6) for SpA and $1.8 \%$ in Norwegian Samis (Lapps) for AS (7). After analysing 36 eligible studies, Dean et al. estimated the average AS prevalence to be $0.319 \%$ in North America, $0.238 \%$ in Europe, $0.167 \%$ in Asia, $0.102 \%$ in Latin America and $0.074 \%$ in Africa (8). The prevalence of psoriatic arthritis varies between $<0.1 \%(9)$ in Czech Republic and $0.4 \%$ in Italy (10), but this maximum value increases up to $42 \%$ in patients with existing psoriasis (1).

The association of HLA-B27 and AS has been documented for more than 40 years (11-14) and approximately $90 \%$ of AS and $60 \%$ of PsA patients are HLA-B27 positive (15). In the last 15 years (16) it has become clear that genes outside the major histocompatibility (MHC) system contribute to the genetic risk of AS and PsA. Several chromosomal regions (1p, 2q, 6p, 9q, 10q, 16q, and 19q) were identified in one of the first genome-wide scans ever performed, pointing to the presence of non-MHC genetic-susceptibility factors in AS (17). Since then, endoplasmic reticulum aminopeptidase (ERAPI) gene and interleukin (IL) 23 receptor gene have been identified as viable candidates by several genome-wide associations studies (GWAS) $(18,19)$, while the involvement of $I L-1$ family gene cluster in AS susceptibility has been less certain $(20,21)$.

Initially, $I L-1$ family gene cluster located on chromosome 2q.14.1-2 and extended across $360.1 \mathrm{~kb}$, included $I L 1 A, I L 1 B$ and $I L-1$ receptor antagonist (IL$1 R N$ ) genes (also called IL-1F1, IL-1F2, IL-1F3 genes). Later on, within the same $360.1 \mathrm{~kb}$ gene cluster, another 6 family members were identified (from $I L-1 F 5$ to $I L-1 F 10$ ) (22), the gene order from centromere to telomere being: ILIA-ILIB-ILIF7-IL1F9IL1F6-IL1F8-IL1F5-IL1F10-ILIRN(23). Along with another two interleukins, IL-18 (IL-1F4) and IL-33 (IL-1F11), located on different chromosomes (chr. 11 and chr. 9, respectively) they form the total 11 members of IL-1 family that we know today (24).

IL- $1 \alpha$ and IL-1 $\beta$ are produced mainly, but not exclusively, by activated macrophages and they are responsible for a wide array of proinflammatory biological activities which comprise the host response to injury and/or infection: fever, acute phase protein synthesis, cytokines (especially TNF- $\alpha$ ) production, up-regulation of adhesion molecules, fibroblast proliferation, vasodilatation, neutrophilia and lymphocytosis $(22,25,26)$.
IL- $1 \alpha$ and IL- $1 \beta$ bind to the same type I IL-1 receptor (IL-1RI) and accessory protein (AcP), also termed co-receptor IL-1RAcP, forming a complex responsible for the intracellular signalling secondary to the IL- $1 \alpha / \beta$ recognition (24). The cytoplasmic Toll-IL-1 receptor (TIR) domains of IL-1RI and IL1RAcP enlist the adapter protein MyD88 (myeloid differentiation primary response gene 88 ), determining the phosphorylation of IRAKs (IL-1R-associated kinases) and IKK $\beta$ (inhibitor of nuclear factor $\kappa \mathrm{B}$ kinase $\beta$ ) (24). As a result NF- $\kappa \mathrm{B}$ is transferred into nucleus, enhancing the expression of many inflammatory genes, such as $I L-6, I L-8, M C P-1, C O X-2$, ILIA, ILIB and MKP-I (27).

IL-1 receptor antagonist (IL-1Ra) encoded by $I L$ $1 R N$ plays the role of a decoy molecule. Although it is recognized by the IL-1RI (like IL-1 $\alpha$ and IL-1 $\beta$ ), this recognition is not followed by the IL-1RAcP attachment and, thus, it fails to carry out the subsequent signalling interactions described above. Furthermore, blocking IL-1RI prevents the agonist molecules (IL-1 $\alpha$ and IL-1 $)$ ) from inducing the proinflammatory effect (22).

ILIA gene polymorphisms have been linked with disease predisposition in seronegative spondyloarthropathies as a whole and in AS in particular (28), while IL-1 $\alpha$ serum levels were elevated in active IBD-SpA compared with inactive IBD-SpA (29).

The aim of this study was to investigate whether two IL1A gene polymorphisms, rs17561 and rs1800587, influence disease susceptibility for seronegative spondyloarthropathies in Romanians. Subsequently, we analysed separately AS and PsA subgroups in relation with the two $I L 1 A$ gene variants.

\section{PATIENTS AND METHODS}

\section{Case-control groups}

The case-control cohorts selected for this study included a total of 400 unrelated Caucasians of Romanian ethnicity: $240 \mathrm{SpA}$ patients $(58.3 \% \mathrm{AS}$ and $41.7 \%$ PsA patients) and 160 healthy controls. The AS patients were diagnosed according to the 1984 modified New York criteria (30), while Classification Criteria for Psoriatic Arthritis (CASPAR) (31) and Assessment of SpondyloArthritis international Society (ASAS) criteria $(32,33)$ were used to diagnose PsA patients in the Rheumatology Departments and Internal Medicine of "Dr. I. Cantacuzino" and "Sfânta Maria" Hospitals, Bucharest. General characteristics for the consecutively enrolled SpA (AS/ 
PsA) patients, as well as for the healthy controls are presented in Table 1.

TABLE 1. Characteristics of the SpA (AS and PsA) patients and healthy controls

\begin{tabular}{|l|c|c|c|c|}
\hline Characteristics & $\begin{array}{c}\text { SpA } \\
\text { patients } \\
(\mathbf{n = 2 4 0})\end{array}$ & $\begin{array}{c}\text { AS } \\
\text { patients } \\
(\mathbf{n}=140)\end{array}$ & $\begin{array}{c}\text { PsA } \\
\text { patients } \\
(\mathbf{n = 1 0 0 )}\end{array}$ & $\begin{array}{c}\text { Controls } \\
(\mathbf{n}=160)\end{array}$ \\
\hline $\begin{array}{l}\text { Average age } \\
\text { (years) }\end{array}$ & 45.3 & 38.9 & 53.2 & 38.1 \\
\hline $\begin{array}{l}\text { Sex ratio } \\
\text { (male:female) }\end{array}$ & $162: 78$ & $118: 22$ & $44: 56$ & $84: 76$ \\
\hline HLA-B27+ \% & $56.5 \%$ & $82.1 \%$ & $20.2 \%$ & $7.7 \%$ \\
\hline
\end{tabular}

HLA-B27+, human leucocyte antigen B27 positive; $S p A$, seronegative spondyloarthropathies; AS, ankylosing spondylitis; PSA, psoriatic arthritis.

The individuals included in the control group are healthy potential organ donors who do not present symptoms and/or history of SpA, screened by the National Institute of Blood Transfusion "Prof. Dr. CT Nicolau", Bucharest. The study had the approval of the local ethics committees and all the subjects recruited signed an informed consent.

DNA extraction was performed using mi-Blood Genomic DNA Isolation Kit - Metabion, Germany and QIAamp DNA Blood Mini Kit Qiagen, Germany, following the manufacturers' protocols. Polymerised chain reaction with specific primers was the principle used for genotyping HLA-B27 using HLAB27-SSP low resolution kit (Olerup, Sweden) and AllSet+TM Gold SSP B27 Low-Resolution Kit (Invitrogen, Life Technologies, Thermo Fisher Scientific, USA).

\section{IL1A genotyping}

A single nucleotide polymorphism (SNP) represents a variation of a single nucleotide which occurs in certain specific position in the genome. Patients and controls were genotyped for two IL1A SNPs chosen based on previous association studies and meta-analysis $(34,35)$. The first $I L 1 A$ polymorphism selected for this study is rs $17561[-340 \mathrm{G} / \mathrm{T}]$ which is located in the coding sequence of IL1A and responsible for a non-synonymous (missense) mutation which changes the peptide structure of IL- $1 \alpha$. The residue change is located in the 114th amino acid position, alanine being replaced by serine in $\mathrm{G}$ to $\mathrm{T}$ allele change (Table 2). The second SNP investigated is rs 1800587 , also known as C-889T, which belongs to a non-coding sequence of the gene, the 5', untranslated region (5'UTR). Although the SNPs located here do not influence the quality of the resulting protein molecule, 5'UTR is an important region which regulates the translation of $\mathrm{mRNA}$ and therefore, changes made here may influence the final quantity of the synthetized polypeptide.

Real-Time PCR with TaqMan ${ }^{\circledR}$ Allelic Discrimination Assays (C__9546471_10 and C 9546481_20) were used to genotype the two SNPs in accordance with the protocols provided by the manufacturer (Thermo Fisher Scientific Inc, Applied Biosystems $^{\mathrm{TM}}$, Foster City, MA, USA).

\section{Statistical analysis}

Hardy-Weinberg equilibrium (HWE) was tested for both SNPs in the control group (36). Allele frequencies and genotype frequencies of each SNP were compared between SpA patients and controls and also between AS and PsA cohorts and controls. The PLINK 1.9 software package (37) assessed the potential associations applying Fisher's Exact test and $\mathrm{p}$ values $\leq 0.05$ were considered significant. The same software was used to calculate haplotypes frequencies and linkage disequilibrium (LD) estimation.

\section{RESULTS}

In the control group minor allele frequencies for both SNPs were higher than those reported for European descendants by HapMap (http://hapmap.ncbi. nlm.nih.gov), even reaching the statistical threshold for $r$ 17561 ( $\mathrm{p}=0.03)$, but closer to the values pre-

TABLE 2. The genotyped IL 1 A gene single nucleotide polymorphisms.

\begin{tabular}{|l|c|c|c|c|}
\hline SNP & $\begin{array}{c}\text { Chromosome } \\
\text { position* }^{*}\end{array}$ & $\begin{array}{c}\text { SNP } \\
\text { location }\end{array}$ & $\begin{array}{c}\text { Gene sequence } \\
\text { Nucleotide change }\end{array}$ & Residue change \\
\hline $\begin{array}{l}\text { rs17561 } \\
\text { [-340G/T] }\end{array}$ & 112779646 & 1300 & $\begin{array}{c}\text { Coding: missense } \\
\text { GCA - TCA }\end{array}$ & A [Ala] 114 S [Ser] \\
\hline $\begin{array}{l}\text { rs1800587 } \\
\text { [C-889T] }\end{array}$ & 112785383 & 12 & $\begin{array}{c}\text { Non-coding: 5'UTR } \\
\text { C-T }\end{array}$ & - \\
\hline
\end{tabular}

*Genome Reference Consortium Human genome build 38; SNP, single-nucleotide polymorphisms; 5' UTR, 5' untranslated region; A [Ala], alanine; S [Ser], serine. 
sented by 1000 Genomes (http://www.1000genomes. org/data).

In the control group, HWE was observed for rs 1800587. A minor deviation was obtained for rs17561 ( $\mathrm{p}=0.03)$. The genotyping rate was $97.5 \%$ for rs 17561 and $99.6 \%$ for rs 1800587 .

LD estimation for the two ILIA polymorphisms identified a high tendency to correlation between the two loci in our population: $\mathrm{r}^{2}=0.75$.

For rs $17561[-340 \mathrm{G} / \mathrm{T}]$ polymorphism, the minor allele $\mathrm{T}$ frequency was similar in general SpA cohort $(31.4 \%)$ compared with controls $(32.8 \%)$, the statistical analyses confirming the lack of association $(\mathrm{p}=0.67)$. Moreover, minor allele carriers, TT and GT genotypes, showed no difference in disease predisposition $(\mathrm{p}=0.42)$. Similar results were found for the second $I L 1 A$ gene variant investigated: rs 1800587 [C-889T]. Minor allele T frequency was $29.1 \%$ in SpA patients and $29.7 \%$ in controls $(\mathrm{p}=0.85)$ and minor allele $\mathrm{T}$ carriers presented the same risk of developing SpA as carriers of CC genotype $(\mathrm{p}=0.74)(\mathrm{Ta}-$ ble 3 ).

The separate analysis of HLA-B27 positive SpA cases had the same outcome. For both ILIA polymorphisms, minor allele frequencies presented little variations between healthy controls $(32.8 \%$ for rs 17561 and $29.7 \%$ for rs1800587) and patients (32.3\% for rs 17561 and $31.8 \%$ for rs 1800587 ), while minor allele carriers had a similar distribution among the two cohorts (Table 3).

A further examination of each subgroup of patients (AS and PsA) against the control cohort was performed. The minor allele frequencies for both polymorphisms investigated in AS patients $(32.2 \%$ for rs 17561 and $31.8 \%$ for rs 1800587 ) were very close to those identified in controls $(32.8 \%$ for rs17561 and 29.7\% for rs1800587); no association with AS susceptibility was revealed (Table 4).

Furthermore, the minor allele frequencies calculated in PsA cohort for both SNPs presented minimal variations from the ones found in controls and these results were mirrored by the distribution of the genotypes in the two cohorts (Table 4).

Additional thorough analysis of HLA-B27 positive AS subgroup or separate male/female examination of SpA subgroups followed the same pattern of non-association.

Haplotype analysis showed almost identical distribution of the haplotypic combinations of rs17561|rs1800587 polymorphisms, resulting in similar haplotype frequencies, in all patients cohorts compared with controls (Table 5). No haplotypic combination, neither minor alleles TT haplotype, nor major alleles GC haplotype, influenced the risk of developing seronegative spondyloarthropathies as a whole, or ankylosing spondylitis and psoriatic arthritis in particular ( $>00.05)$ (Table 5).

\section{DISCUSSIONS AND CONCLUSIONS}

This is the first Romanian based genetic association study which investigates the relation between ILIA gene variants and SpA. Our results show that the IL1A gene polymorphisms (rs17561 [-340G/T] and rs1800587 [C-889T]) do not influence the disease predisposition to seronegative spondyloarthropathies in general, nor for ankylosing spondylitis and psoriatic arthritis in particular, in Romanians.

TABLE 3. Minor allele frequencies and genotypes frequencies for rs17561 and rs1800587 in SpA patients and HLA-B27 positive SpA patients versus controls

\begin{tabular}{|c|c|c|c|c|c|}
\hline SNP & Controls & SpA & Statistics & HLA-B27+ SpA & Statistics \\
\hline rs17561 & $n=160$ & $n=234$ & & $n=130$ & \\
\hline \multirow[t]{2}{*}{ Minor allele $\mathrm{T}$} & $\begin{array}{c}\text { Number } \\
\text { (frequency) }\end{array}$ & $\begin{array}{c}\text { Number } \\
\text { (frequency) }\end{array}$ & \multirow{2}{*}{$\begin{array}{c}\text { OR } 0.938 \\
\text { C.I. }=[0.69-1.27] \\
p=0.67\end{array}$} & $\begin{array}{c}\text { Number } \\
\text { (frequency) }\end{array}$ & \multirow{2}{*}{$\begin{array}{c}\text { OR } 0.977 \\
\text { C.I. }=[0.68-1.38] \\
p=0.89\end{array}$} \\
\hline & $105(32.8 \%)$ & $147(31.4 \%)$ & & $84(32.3 \%)$ & \\
\hline Genotype TT+GT & $11+83(58.7 \%)$ & $\begin{array}{l}19+109 \\
(54.7 \%)\end{array}$ & $\begin{array}{c}\text { OR } 0.848 \\
\text { C.I. }=[0.56-1.27] \\
p=0.42\end{array}$ & $10+64(56.9 \%)$ & $\begin{array}{c}\text { OR } 0.928 \\
\text { C.I. }=[0.58-1.48] \\
p=0.75\end{array}$ \\
\hline rs1800587 & $n=160$ & $n=239$ & & $n=132$ & \\
\hline \multirow[t]{2}{*}{ Minor allele $\mathrm{T}$} & $\begin{array}{c}\text { Number } \\
\text { (frequency) }\end{array}$ & $\begin{array}{c}\text { Number } \\
\text { (frequency) }\end{array}$ & \multirow{2}{*}{$\begin{array}{c}\text { OR } 0.971 \\
\text { C.I. }=[0.71-1.32] \\
p=0.85\end{array}$} & $\begin{array}{c}\text { Number } \\
\text { (frequency) }\end{array}$ & \multirow{2}{*}{$\begin{array}{c}\text { OR } 1.105 \\
\text { C.I. }=[0.77-1.57] \\
p=0.57\end{array}$} \\
\hline & $95(29.7 \%)$ & $139(29.1 \%)$ & & $84(31.8 \%)$ & \\
\hline Genotype TT+CT & $14+67(50.7 \%)$ & $22+95(49 \%)$ & $\begin{array}{c}\text { OR } 0.935 \\
\text { C.I. }=[0.62-1.39] \\
p=0.74\end{array}$ & $14+56(53 \%)$ & $\begin{array}{c}\text { OR 1.101 } \\
\text { C.I. }=[0.69-1.74] \\
p=0.68\end{array}$ \\
\hline
\end{tabular}

$S p A$, seronegative spondyloarthropathies; HLA-B27+, human leucocyte antigen B27 positive;

SNP, single-nucleotide polymorphisms, Cl, 95\% confidence interval; OR, odds ratio; $p$ values $<0.05$ are considered significant. 
TABLE 4. Minor allele frequencies and genotypes frequencies for both SNPs investigated in AS patients and PSA patients versus controls

\begin{tabular}{|c|c|c|c|c|c|}
\hline SNP & Controls & AS & Statistics & PsA & Statistics \\
\hline rs17561 & $n=160$ & $n=135$ & & $n=99$ & \\
\hline \multirow[t]{2}{*}{ Minor allele $\mathrm{T}$} & $\begin{array}{c}\text { Number } \\
\text { (frequency) }\end{array}$ & $\begin{array}{c}\text { Number } \\
\text { (frequency) }\end{array}$ & \multirow{2}{*}{$\begin{array}{c}\text { OR } 0.973 \\
\text { C.I. }=[0.68-1.37] \\
p=0.87\end{array}$} & $\begin{array}{c}\text { Number } \\
\text { (frequency) }\end{array}$ & \multirow{2}{*}{$\begin{array}{c}\text { OR } 0.890 \\
\text { C.I. }=[0.60-1.30] \\
p=0.55\end{array}$} \\
\hline & $105(32.8 \%)$ & $87(32.2 \%)$ & & $60(30.3 \%)$ & \\
\hline $\begin{array}{l}\text { Genotype } \\
\text { TT+GT }\end{array}$ & $11+83(58.7 \%)$ & $11+65(56.3 \%)$ & $\begin{array}{c}\text { OR } 0.904 \\
\text { C.I. }=[0.56-1.43] \\
p=0.67\end{array}$ & $8+44(52.5 \%)$ & $\begin{array}{c}\text { OR } 0.777 \\
\text { C.I. }=[0.46-1.28] \\
p=0.32\end{array}$ \\
\hline rs1800587 & $n=160$ & $n=139$ & & $n=100$ & \\
\hline \multirow[t]{2}{*}{ Minor allele $\mathrm{T}$} & $\begin{array}{c}\text { Number } \\
\text { (frequency) }\end{array}$ & $\begin{array}{c}\text { Number } \\
\text { (frequency) }\end{array}$ & \multirow{2}{*}{$\begin{array}{c}\text { OR } 1.043 \\
\text { C.I. }=[0.73-1.48] \\
p=0.81\end{array}$} & $\begin{array}{c}\text { Number } \\
\text { (frequency) }\end{array}$ & \multirow{2}{*}{$\begin{array}{c}\text { OR } 0.876 \\
\text { C.I. }=[0.59-1.29] \\
p=0.50\end{array}$} \\
\hline & $95(29.7 \%)$ & $85(31.8 \%)$ & & $54(27 \%)$ & \\
\hline $\begin{array}{l}\text { Genotype } \\
\text { TT+CT }\end{array}$ & $14+67(50.7 \%)$ & $14+57(61.1 \%)$ & $\begin{array}{c}\text { OR } 1.018 \\
\text { C.I. }=[0.64-1.60] \\
p=0.93\end{array}$ & $8+38(46 \%)$ & $\begin{array}{c}\text { OR } 0.831 \\
\text { C.I. }=[0.50-1.37] \\
p=0.46\end{array}$ \\
\hline
\end{tabular}

AS, ankylosing spondylitis; PsA, psoriatic arthritis; SNP, single-nucleotide polymorphisms, Cl, 95\% confidence interval; OR, odds ratio; $p$ values $<0.05$ are considered significant.

TABLE 5. IL1A rs17561|rs1800587 haplotype frequencies for the investigated cohorts

\begin{tabular}{|l|c|c|c|c|c|c|c|}
\hline Haplotype & $\begin{array}{c}\text { Controls } \\
(\mathbf{n = 1 6 0 )}\end{array}$ & $\begin{array}{c}\text { SpA } \\
(\mathbf{n = 2 3 3 )}\end{array}$ & $\mathbf{p}$ & $\begin{array}{c}\text { AS } \\
(\mathbf{n = 1 3 4 )}\end{array}$ & $\mathbf{p}$ & $\begin{array}{c}\text { PsA } \\
(\mathbf{n = 9 9})\end{array}$ & $\mathbf{p}$ \\
\hline TT & 0.281 & 0.279 & 0.94 & 0.294 & 0.71 & 0.257 & 0.55 \\
\hline GT & 0.015 & 0.012 & 0.74 & 0.011 & 0.64 & 0.015 & 0.96 \\
\hline TC & 0.046 & 0.036 & 0.46 & 0.029 & 0.28 & 0.045 & 0.94 \\
\hline GC & 0.656 & 0.671 & 0.65 & 0.664 & 0.83 & 0.681 & 0.54 \\
\hline
\end{tabular}

$S p A$, seronegative spondyloarthropathies; AS, ankylosing spondylitis; PsA, psoriatic arthritis; $S N P$, single-nucleotide polymorphisms, $p$ values $<0.05$ are considered significant.

The reports regarding $I L 1$ gene cluster located on chromosome $2 \mathrm{q} 14$ as a susceptibility locus for AS and PsA have been controversial since the early genetic studies $(20,21,38)$. Genome wide association studies $(18,39)$, including the most recent International Genetics of Ankylosing Spondylitis Consortium GWAS (40) did not detect this locus among the ones being associated with AS, although loci located on chromosome 2q11 encoding ILIRI and ILIR2 showed suggestive association with AS in Europeans (40). However, there are multiple association studies and meta-analyses which seem to implicate $I L 1 A, I L 1 B$ or $I L 1 R N$ gene polymorphisms as a risk factor for AS, PsA and SpA as a whole in various populations. One of the most cited studies examined three Canadian populations and identified several SNPs belonging to $I L-1$ gene cluster as being associated with the risk of AS. Three IL1A gene polymorphisms were reported (rs3783550, rs3783543 and rs3783526), but, interestingly, the ones we investigated, rs17561 and rs1800794, showed no association with the disease (34). Similarly, IL1A polymorphism rs 1800587 [-889C/T] was not associated with
HLA-B27 positive AS in Iranians, although $I L 1 R$ polymorphism rs2234650 did influence the risk of developing AS (41). A Korean study investigated 51 SNPs within $I L-1$ gene cluster, including $I L 1 A$ polymorphisms, and even though haplotype analysis revealed an association with AS, the study failed to identify any individual SNP association with AS susceptibility (42). Another study investigating an Asian population found that $I L-1$ gene cluster is associated with AS in Chinese population (43). An early metaanalysis which included 6 studied and nine population samples, investigated $I L-1$ gene complex and disease susceptibility for AS and reported among the relevant SNPs IL1A rs1800587 [C-889T] (44). A prospective meta-analyses aimed to determine the contribution of $I L-1$ gene cluster to AS susceptibility in different populations identified three ILIA gene variants (rs17561, rs2856836, rs1894399) as having a strong association with AS (45). Another metaanalysis, comprising nine studies with population samples from Europe, Asia and Latin America, revealed that several SNPs belonging to $I L-1$ gene cluster, including the ones we investigated (rs17561 
[-340G/T], rs1800587 [C-889T]) present a significant association with AS, especially in Europeans (35). Similarly, $I L-1 R N$ polymorphisms were found to be implicated in AS pathogenesis (46).

The first report involving ILIA gene polymorphisms in PsA identified rs1800587 [C-889T] as a risk factor (47). Two years later, Rahman et al. reported two regions within $I L-1$ gene complex contributing independently to the risk of disease in PsA: ILIA gene (rs3783547, rs3783543 and rs17561) and a region near the end of $I L 1 B$, through $\mathrm{IL}-1 F 7, I L$ $1 F 8$, and into $I L-1 F 10$ (48).

Monnet et al. (28) were the first to report that ILIA gene polymorphisms are associated with SpA as a whole and with AS susceptibility in particular. $I L 1 A$ gene seems to influence also the AS phenotype, mainly sacroiliitis' severity (28). A significant variation of IL-1 $\alpha$ and IL-1Ra serum levels in active enteropathic (IBD) SpA compared with inactive IBD-SpA was described (29), although a recent study found no statistical differences in $I L 1 A, I L 1 B$ and ILIRN genotypes and allele distributions between IBD cases and healthy controls (49).

The results reported in the literature regarding the involvement of $I L-1$ gene complex in $\mathrm{SpA}$ and AS susceptibility are conflicting. Furthermore, IL-1 blocking agent Anakinra, a recombinant IL1-Ra, approved for the treatment of rheumatoid arthritis patients, showed limited efficacy in AS (50) and PsA patients (51), while no large trials are currently evaluating its role in $\mathrm{SpA}$ (52). It is possible that some discrepancies between studies can be explained by study design or power limitations (53), but a more likely reason for the contrasting results may be disease heterogeneity itself. Spondyloarthropathies are multifactorial genetic disorders and the genetic factors implicated in disease susceptibility may differ from one population to another, which could explain why negative association studies, like ours, can coexist with positive ones. However, it has been hypothesized that $I L-1$ gene cluster's contribution to $\mathrm{SpA}$ is closely related to other non-MHC gene susceptibility variants more firmly identified (ERAP1, $I L-23 R$ ) (53), but only further studies can pinpoint the exact role of $I L-1$ gene complex, particularly of ILIA gene, in SpA pathogenesis.

\section{ACKNOWLEDGEMENTS}

Olivia Mihaela Popa was supported by the University of Medicine and Pharmacy "Carol Davila" Young Research Project TC 28350/04.11.2013.

\section{REFERENCES}

1. Zochling J., Smith E.U. Seronegative spondyloarthritis. Best Pract Res Clin Rheumatol. 2010; 24(6):747-56.

2. Braun J., Sieper J. [Spondyloarthritides]. Z Rheumatol. 2010 69(5):425-32.

3. Landewe R.B., van der Heijde D.M. [The recognition of patients with spondyloarthritis. New classification criteria]. Ned Tijdschr Geneeskd. 2011; 155(30-31).

4. Stolwijk C., Boonen A., van Tubergen A., Reveille J.D. Epidemiology of spondyloarthritis. Rheumatic diseases clinics of North America. 2012; 38(3):441-76.

5. Hukuda S., Minami M., Saito T., Mitsui H., Matsui N., Komatsubara Y., et al. Spondyloarthropathies in Japan: nationwide questionnaire survey performed by the Japan Ankylosing Spondylitis Society. The Journal of rheumatology. 2001; 28(3):554-9.

6. Boyer G.S., Templin D.W., Cornoni-Huntley J.C., Everett D.F., Lawrence R.C., Heyse S.F., et al. Prevalence of spondyloarthropathies in Alaskan Eskimos. The Journal of rheumatology. 1994; 21(12):2292-7.

7. Johnsen K., Gran J.T., Dale K., Husby G. The prevalence of ankylosing spondylitis among Norwegian Samis (Lapps). The Journal of rheumatology. 1992; 19(10):1591-4.

8. Dean L.E., Jones G.T., MacDonald A.G., Downham C., Sturrock R.D., Macfarlane G.J. Global prevalence of ankylosing spondylitis. Rheumatology (Oxford, England). 2014;53(4):650-7.

9. Hanova P., Pavelka K., Holcatova I., Pikhart H. Incidence and prevalence of psoriatic arthritis, ankylosing spondylitis, and reactive arthritis in the first descriptive population-based study in the Czech Republic. Scandinavian journal of rheumatology. 2010; 39(4):310-7.

10. De Angelis R., Salaffi F., Grassi W. Prevalence of spondyloarthropathies in an Italian population sample: a regional community-based study. Scandinavian journal of rheumatology. 2007; 36(1):14-21.

11. Truog P., Steiger U., Loewi G., Neuhaus K. [HL-A B27 associated rheumatic disease]. Schweiz Med Wochenschr. 1975; 105(50):1733-5.

12. Brewerton D.A., Hart F.D., Nicholls A., Caffrey M., James D.C., Sturrock R.D. Ankylosing spondylitis and HL-A 27. Lancet. 1973; 1(7809):904-7.

13. Reveille J.D. The genetic basis of ankylosing spondylitis. Current opinion in rheumatology. 2006; 18(4):332-41.

14. Brionez T.F., Reveille J.D. The contribution of genes outside the major histocompatibility complex to susceptibility to ankylosing spondylitis. Current opinion in rheumatology. 2008; 20(4):384-91.

15. Diamond. LHBCEHS. Ankylosing Spondylitis and Undifferentiated Spondyloarthropathy WorkupUpdated: Apr 16, 2012.

16. Brown M.A., Laval S.H., Brophy S., Calin A. Recurrence risk modelling of the genetic susceptibility to ankylosing spondylitis. Annals of the rheumatic diseases. 2000; 59(11):883-6.

17. Laval S.H., Timms A., Edwards S., Bradbury L., Brophy S., Milicic A., et al. Whole-genome screening in ankylosing spondylitis: evidence of non-MHC genetic-susceptibility loci. American journal of human genetics. 2001; 68(4):918-26.

18. Burton P.R. CD, Cardon L.R., Craddock N., Deloukas P., Duncanson A., et al, for The Australo-Anglo-American Spondylitis Consortium (TASC). Association scan of 14,500 nonsynonymous SNPs in four diseases identifies autoimmunity variants. Nat Genet. 2007; 39(11):1329-37. 
19. The Australo-Anglo-American Spondyloarthritis Consortium (TASC) R.J., et al. Genome-wide association study of ankylosing spondylitis identifies non-MHC susceptibility loci. Nat Genet. 2010; 42(2):123-7

20. Djouadi K., Nedelec B., Tamouza R., Genin E., Ramasawmy R., Charron D., et al. Interleukin 1 gene cluster polymorphisms in multiplex families with spondylarthropathies. Cytokine. 2001; 13(2):98-103.

21. van der Paardt M., Crusius J.B., Garcia-Gonzalez M.A., Baudoin P., Kostense P.J., Alizadeh B.Z., et al. Interleukin1 beta and interleukin-1 receptor antagonist gene polymorphisms in ankylosing spondylitis. Rheumatology (Oxford, England). 2002; 41(12):1419-23

22. Smith D.E., Renshaw B.R., Ketchem R.R., Kubin M., Garka K.E., Sims J.E. Four new members expand the interleukin-1 superfamily. The Journal of biological chemistry. 2000; 275(2):1169-75.

23. Nicklin M.J., Barton J.L., Nguyen M., FitzGerald M.G., Duff G.W., Kornman K. A sequence-based map of the nine genes of the human interleukin-1 cluster. Genomics. 2002; 79(5):718-25.

24. Dinarello C.A. Interleukin-1 in the pathogenesis and treatment of inflammatory diseases. Blood. 2011; 117(14):3720-32.

25. Dinarello C.A. Interleukin-1, interleukin-1 receptors and interleukin-1 receptor antagonist. International reviews of immunology. 1998; 16(5-6):457-99.

26. Garlanda C., Dinarello C.A., Mantovani A. The Interleukin-1 family: back to the future. Immunity. 2013; 39(6):1003-18.

27. Weber A., Wasiliew P., Kracht M. Interleukin-1 (IL-1) pathway. Science signaling. 2010; 3(105):cm1.

28. Monnet D., Kadi A., Izac B., Lebrun N., Letourneur F., Zinovieva E., et al. Association between the IL-1 family gene cluster and spondyloarthritis. Annals of the rheumatic diseases. 2012 71(6):885-90.

29. Vounotrypidis P., Kouklakis G., Anagnostopoulos K., Zezos P., Polychronidis A., Maltezos E., et al. Interleukin-1 associations in inflammatory bowel disease and the enteropathic seronegative spondylarthritis. Auto- immunity highlights. 2013; 4(3):87-94.

30. van der Linden S., Valkenburg H.A., Cats A. Evaluation of diagnostic criteria for ankylosing spondylitis. A proposal for modification of the New York criteria. Arthritis and rheumatism. 1984; 27(4):361-8

31. Taylor W., Gladman D., Helliwell P., Marchesoni A., Mease P., Mielants H. Classification criteria for psoriatic arthritis: development of new criteria from a large international study. Arthritis and rheumatism. 2006; 54(8):2665-73.

32. Rudwaleit M., van der Heijde D., Landewe R., Listing J., Akkoc N., Brandt J., et al. The development of Assessment of SpondyloArthritis international Society classification criteria for axial spondyloarthritis (part II): validation and final selection. Annals of the rheumatic diseases. 2009; 68(6):777-83.

33. Rudwaleit M., van der Heijde D., Landewe R., Akkoc N., Brandt J., Chou C.T., et al. The Assessment of SpondyloArthritis International Society classification criteria for peripheral spondyloarthritis and for spondyloarthritis in general. Annals of the rheumatic diseases. 2011; 70(1):25-31.

34. Maksymowych W.P., Rahman P., Reeve J.P., Gladman D.D., Peddle L., Inman R.D. Association of the IL1 gene cluster with susceptibility to ankylosing spondylitis: an analysis of three Canadian populations. Arthritis and rheumatism. 2006; 54(3):974-85.

35. Lea W.I., Lee Y.H. The associations between interleukin-1 polymorphisms and susceptibility to ankylosing spondylitis: a meta-analysis. Joint, bone, spine: revue du rhumatisme. 2012; 79(4):370-4

36. Wigginton J.E., Cutler D.J., Abecasis G.R. A note on exact tests of Hardy-Weinberg equilibrium. Am J Hum Genet. 2005; 76:887-93.

37. Chang C.C., Chow C.C., Tellier L.C., Vattikuti S., Purcell S.M., Lee J.J. Second-generation PLINK: rising to the challenge of larger and richer datasets. GigaScience. 2015; 4:7.
38. Timms A.E., Crane A.M., Sims A.M., Cordell H.J., Bradbury L.A., Abbott A., et al. The interleukin 1 gene cluster contains a major susceptibility locus for ankylosing spondylitis. American journal of human genetics. 2004; 75(4):587-95.

39. Reveille J.D., Sims A.M., Danoy P., Evans D.M., Leo P., Pointon J.J., et al. Genome-wide association study of ankylosing spondylitis identifies non-MHC susceptibility loci. Nat Genet. 2010; 42(2):123-7

40. International Genetics of Ankylosing Spondylitis C., Cortes A., Hadler J., Pointon J.P., Robinson P.C., Karaderi T., et al. Identification of multiple risk variants for ankylosing spondylitis through high-density genotyping of immune-related loci. Nature genetics. 2013; 45(7):730-8.

41. Mahmoudi M., Amirzargar A.A., Jamshidi A.R., Farhadi E., Noori S., Avraee M., et al. Association of IL1R polymorphism with HLA-B27 positive in Iranian patients with ankylosing spondylitis. European cytokine network. 2011; 22(4):175-80.

42. Kim T.J., Kim T.H., Lee H.J., Peddle L., Rahman P., Hu P., et al. Interleukin 1 polymorphisms in patients with ankylosing spondylitis in Korea. The Journal of rheumatology. 2008; 35(8):1603-8.

43. Guo Z.S., Li C., Lin Z.M., Huang J.X., Wei Q.J., Wang X.W., et al. Association of IL-1 gene complex members with ankylosing spondylitis in Chinese Han population. International journal of immunogenetics. 2010; 37(1):33-7.

44. Wu Z., Gu J.R. [A meta-analysis on interleukin-1 gene cluster polymorphism and genetic susceptibility for ankylosing spondylitis]. Zhonghua yi xue za zhi. 2007; 87(7):433-7.

45. Sims A.M., Timms A.E., Bruges-Armas J., Burgos-Vargas R., Chou C.T., Doan T., et al. Prospective meta-analysis of interleukin 1 gene complex polymorphisms confirms associations with ankylosing spondylitis. Annals of the rheumatic diseases. 2008; 67(9):1305-9.

46. Jin G.X., Duan J.Z., Guo W.L., Li L., Cui S.Q., Wang H. Association between IL-1RN gene polymorphisms and susceptibility to ankylosing spondylitis: a large Human Genome Epidemiology review and meta-analysis. Genetics and molecular research : GMR. 2013; 12(2):1720-30.

47. Ravindran J.S., Owen P., Lagan A., Lewis J., Korendowych E., Welsh K., et al. Interleukin 1alpha, interleukin 1beta and interleukin 1 receptor gene polymorphisms in psoriatic arthritis. Rheumatology (Oxford, England). 2004; 43(1):22-6.

48. Rahman P., Sun S., Peddle L., Snelgrove T., Melay W., Greenwood C., et al. Association between the interleukin-1 family gene cluster and psoriatic arthritis. Arthritis and rheumatism. 2006; 54(7):2321-5.

49. Lopez-Hernandez R., Valdes M., Campillo J.A., Martinez-Garcia P., Salama H., Bolarin J.M., et al. Pro- and anti-inflammatory cytokine gene single-nucleotide polymorphisms in inflammatory bowel disease. International journal of immunogenetics. 2015; 42(1):38-45.

50. Bennett A.N., Tan A.L., Coates L.C., Emery P., Marzo-Ortega H., McGonagle D. Sustained response to anakinra in ankylosing spondylitis. Rheumatology (Oxford, England). 2008; 47(2):223-4.

51. Jung N., Hellmann M., Hoheisel R., Lehmann C., Haase I., Perniok A., et al. An open-label pilot study of the efficacy and safety of anakinra in patients with psoriatic arthritis refractory to or intolerant of methotrexate (MTX). Clinical rheumatology. 2010; 29(10):1169-73.

52. Bruner V., Atteno M., Spanò A., Scarpa R., Peluso R. Biological therapies for spondyloarthritis. Therapeutic advances in musculoskeletal disease. 2014; 6(3):92-101.

53. Tsui F.W., Tsui H.W., Akram A., Haroon N., Inman R.D. The genetic basis of ankylosing spondylitis: new insights into disease pathogenesis. The application of clinical genetics. 2014; 7:105-15. 